\title{
A comparison between James and Philodemus on moral exhortation, communal confession and correctio fraterna
}

Author:

Jacobus Kok

Affiliation:

${ }^{1}$ Department of New Testament Studies, University of Pretoria, South Africa

Correspondence to:

Kobus Kok

Email:

kobus.kok@up.ac.za

\section{Postal address:}

University of Pretoria,

Department of New

Testament Studies,

Lynwood Road, Pretoria

0181, South Africa

Dates:

Received: 25 Jan. 2013

Accepted: 12 Apr. 2013

Published: 26 June 2013

How to cite this article: Kok, J., 2013, 'A comparison between James and Philodemus on moral exhortation, communal confession and correctio fraterna', HTS Teologiese Studies/Theological Studies 69(1), Art. \#1927, 8 pages. http://dx.doi.org/10.4102/ hts.v69i1.1927

\section{Copyright:}

(C) 2013. The Authors.

Licensee: AOSIS OpenJournals. This work is licensed under the Creative Commons Attribution License.
Read online:
In this article, James 5:13-20 is investigated. This section deals with the confession of sins in the community of faith and the subsequent healing that will result. James will be compared to Philodemus, a philosopher who comes from Galilee, just like James. It is not argued that James was influenced by Philodemus but that a comparison between the two might open up fresh perspectives for the interpretation of James 5:13-20. This will especially become clear when the themes of moral exhortation, community health, communal confession and the role of the psychagogue are discussed.

\section{Introduction}

Glad (1995) did extensive research into the relationship between Philodemus and $\mathrm{Paul}^{1}$ as far as the issue of the adaptability in Epicurean and Early Christian psychagogy is concerned. Apart from this research, very little has been written, according to my knowledge, on the relationship between James and Philodemus. In this article, I shall attempt to illustrate some comparisons between James and Philodemus in order to illuminate the similarities and uniqueness of both. This might shed fresh light on the interpretation of James or at least on how James might have been heard or read by ancient people familiar with perspectives like that of Philodemus. ${ }^{2}$

James $^{3} 5: 13-20$ deals with the confession of sins in the community of faith and the subsequent healing that will result. Firstly, I shall discuss the section in James and then compare the results with material written by Philodemus, a philosopher who also came from Galilee, just like James (Martin 1988:ixxi; Rendall 1927:39). Here I am not arguing that James was influenced by Philodemus, but that a comparison between the two might open up fresh perspectives for the interpretation of James 5:13-20 and the function of communal confession and moral exhortation in ancient times.

In James 5:13-20, the author states:

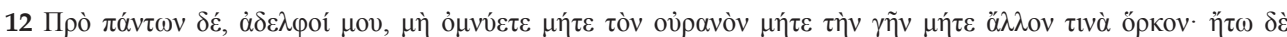

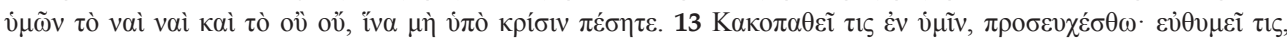

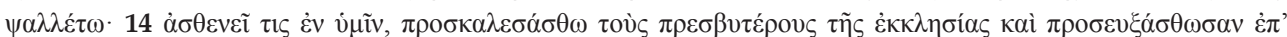

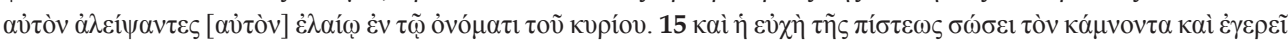

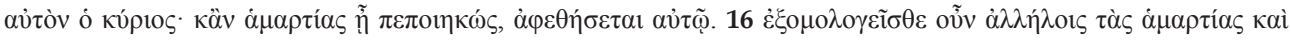

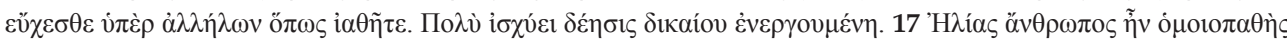

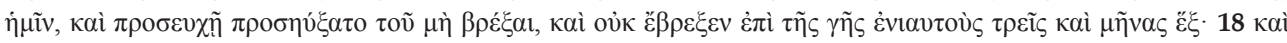

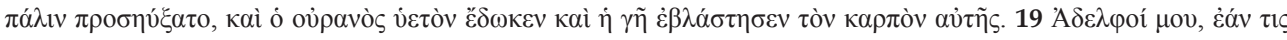

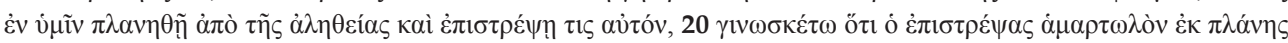

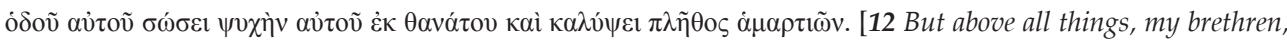
swear not, neither by the heaven, nor by the earth, nor by any other oath: but let your yes be yes, and your no, be no, so that you fall not under judgment. 13 Is any among you suffering? Let him pray. Is any cheerful? Let him sing praise. 14 Is any among you sick? Let him call for the elders of the church; and let them pray over him, anointing him with oil in the name of the Lord: 15 and the prayer of faith shall save the sick person, and the Lord shall raise him up; and if he have committed sins, it shall be forgiven him. 16 Confess therefore your sins one to another, and pray one for another, that you may be healed. The supplication of a righteous man avails much in its working. 17 Elijah was a man of like passions with us, and he prayed fervently that it might not rain; and it rained not on the earth for three years and six months. 18 And he prayed again; and the heaven gave rain, and the earth brought forth her fruit. $19 \mathrm{My}$ brethren, if any among you err from the truth, and one convert him; 20 let him know, that he who converts a sinner from the error of his way shall save a soul from death, and shall cover a multitude of sins. $]^{4}$

1.See also Sampley (2004:295).

2.See Fitzgerald, Obbink and Holland (2004); cf. Konstan et al. (1998).

3.In the New Testament, we know of at least six people called James (cf. Mt 27:56; Mk 3:16-19; 15:40; 16:1; Lk 24:10). The letter of James was most probably written by James, the brother of Jesus Christ round about in the year 62 CE, before James' death (cf. Gl 1:19). Traditionally, James was placed within the framework of 'Jewish Christianity' (cf. the Baur school), that section of the Jesus movement with its negative attitude towards Paul (Martin 1988:xlii). Consequently, most of James' teaching has been interpreted against a Jewish background.

4.Translation from the American Standard Version. 


\section{Homo duplex in Philodemus and James}

In moral philosophical thought, it was no compliment if someone was labelled as being inconsistent in her or his ways. It was important for people to be steadfast and honest and not to change whenever they needs to please people, making them servile and inconsistent flatterers - sycophants (Glad 1995:16; Kok 2012). The idea of the sycophant appears as early as Homer's Odysseus, referring to the polytrophic man of many turns ( $\pi \circ \lambda v i \rho \circ \pi \circ \varsigma)$, and in an etymological study of the term, it becomes clear that, in the 5th century $\mathrm{BCE}$, it referred to people who often changed their character, who were unprincipled and unscrupulous (Glad 1995:19; Kok 2012). In the ethical interpretation of that time, Odysseus became the archetype of the deceitful homo duplex ( $\pi \mathrm{o} \lambda \dot{\tau} \tau \rho \circ \pi \mathrm{o})$ ), and Achilles became the candid homo simplex ( $\dot{\alpha} \pi \lambda$ oṽ $\varsigma)$ who reveals his true motivations and intentions (Glad 1995, 19; cf. also Plato ${ }^{5}$, Lesser Hippias, 364 BCE; 365B. cf. also Thaetus 146D; Kok 2012). Plutarch, (according to Glad 1995:29) in his How to tell a flatterer from a friend (52 FAB; $51 \mathrm{D}$ ) refers to the flatterers who can associate with all and go to great lengths to imitate those they wants to impress:

With one he joins in dancing and singing, with another in wrestling or hunting, with still another in scholarly pursuits ... [T]he friend of many can often change himself instantaneously from one character to another ... (Glad 1995:29; cf. Plutarch, Alcibiades 2.1; 26.5; 23.4; Kok 2012)

This often happened when clients wanted to impress their benefactors. The flatterer, who was the opposite of the true friend, could not only easily pass from one style of life to another but could even undergo a radical change of character and take on a counterfeit exterior to suit the context and be acceptable to those whom she or he attempted to please (Plutarch, Alcibiades 23.5; cf. Glad 1995:30). These flatterers were like parasites who attached themselves to patrons with the aim of securing for themselves the maximum advantage and making themselves exteriorly agreeable and conforming to the needs of the moment in an inauthentic way (Glad 1995:29-30, 86; Kok 2012).

It is interesting to note that James also has a case against those with double-mindedness and mentions it in terms similar to those used by Philodemus and other moral philosophers

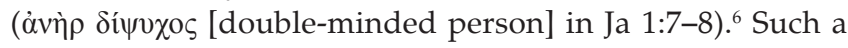
person is like the surge of the sea, driven by the wind and

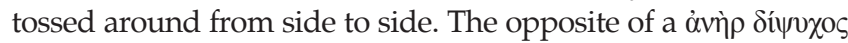
is someone with a firm basis, who is stable in her or his ways and who can endure temptation (1:12a). James says in 1:6-7: 'If anyone lacks wisdom, let him ask God, who gives to all men generously and without reproaching, and wisdom will be given to him.' Here James urges the believers to see God as their patron and themselves as the clients. As patron, God gives wisdom to those who ask. However, in ancient times,

5.See Plato, Lesser Hippias, 364 BCE; 365B; cf. also Thaetus 146D for a discussion of the contrasts between homo duplex and homo simplex.

6.Sleeper (1998:51) states that the adjective 'double-minded' appears in James 1:8 for the first time in any literature (cf. 1 Clem 23:3-4; 2 Clem 11:2-3). Sleeper does not refer to any other sources pertaining to Greco-Roman philosophy. benefaction was always reciprocal. The one who receives has the obligation to give either a gift of similar value or loyalty and even life-long obligation. Since believers cannot match what God has given, they owe God lifelong loyalty (Kok \& Van Eck 2011).

\section{Christian and Epicurean community ethics}

Believers should, inter alia, illustrate the fact that they are a community with a distinct identity. This they shared with the Epicureans, who also formed genuine communities of people who shared one another's lives on an intimate level. Like the Christians had Jesus as their founder and leaders like James in continuation with Jesus' tradition, so the Epicureans saw themselves as followers of Epicurus, the one who started the movement (Malherbe 1987:5; Glad 1995:5). James also describes his group as individuals who belong to the same family, having their origin in Jesus and the Father. They form an alternative kinship family structure. Therefore James, like Paul, calls the believers that he is leading my brothers (Ja 1:2- $\alpha \delta \varepsilon \lambda$ poí $\mu$ ov). In ancient times, and within the framework of ancient family structure, absolute loyalty to the group was a perquisite. Members were responsible for one another. James exhorts (cf. Ja 1:2 - i $\gamma \dot{\eta} \sigma \alpha \sigma \theta \varepsilon$, imperative) the believers to remember the implications of their identity. As children of God and brothers of an alternative fictive kinship group, they already know the spiritual truth, namely that the testing of faith produces steadfastness and moral

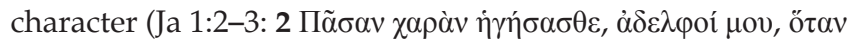

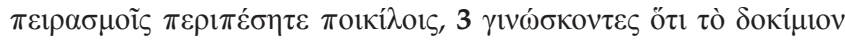

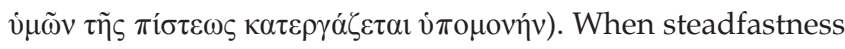
eventually has its full effect, it produces a person who is

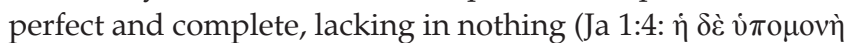

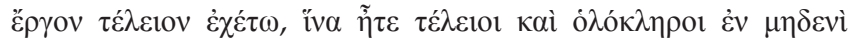
$\lambda \varepsilon ı$ ó $\mu \varepsilon v o 1)$. Likewise, Epicureanism had in mind the moral reformation of its members, similar to early Christ-followers. Just like Epicurean psychogogues' exhortation was aimed at moral reformation so the early Christian communities were also aimed at building community and exhorting moral reformation and growth, as clearly seen in protreptic and apotreptic rhetoric in the New Testament (cf. Glad 1995:7).

\section{True friends and psychagogues speak honestly and frankly}

The work of Philodemus ${ }^{7}$ (On frank criticism [ $\left.\pi \varepsilon \rho i ̀ ~ \pi \alpha \rho \rho \eta \sigma i ́ \alpha\right]$ ], papyrus $(\delta 1 \sigma \varepsilon \gamma v \mathrm{r})$ documents discovered at Herculaneum (18th century) $)^{8}$ sheds important light on the relationship between classical culture and early Christianity since his work deals with moral improvement and the techniques of pedagogy, which would also later become important for the Christian movement (Fitzgerald 1998:vii; Kok 2012).

\footnotetext{
7.Philodemus was born in Gadara, Syria, in 110 BCE and died round about 40 BCE. Amongst the work discovered in the house of Herculaneum were Philodemus' lecture notes from classes by Zeno which he attended in Athens. The work of Philodemus sheds important light on the social history of Epicurism. In 1998, a translation of his On frank criticism was published by the Hellenistic Moral Philosophy and Early Christianity group (Fitzgerald 1998:vii-ix)
}

8.The original work of Philodemus is kept in the National Library in Naples. 
Fitzgerald and others (1998:3-5) give an overview of the word $\pi \alpha \rho \rho \eta \sigma i \alpha$ [frank speech] from classical Athenian democracy until the time of Philodemus. In the time of the classical democracy, $\pi \alpha \rho \rho \eta \sigma i \alpha$ referred to the right of free speech of those who had full civic status in Athens without fear of being punished by more powerful individuals typical of democracy. At this stage, $\pi \alpha \rho \rho \eta \sigma i ́ \alpha$ had no specific connotation to friendship. Only during and after the time of Isocrates was $\pi \alpha \rho \rho \eta \sigma i \alpha$ used to refer to frankness of speech within the context of friendship and did it receive the connotation of a private virtue. During this time, the nature of friendship also changed: $\pi \alpha \rho \rho \eta \sigma i \alpha$ changed from being a political right to becoming a private virtue (Fitzgerald 1998:3). Slowly but surely, $\pi \alpha \rho \rho \eta \sigma i \alpha$ denoted an important sign of true friendship which was characterised by honesty, integrity and frankness. In the writings of philosophers (cf. Plutarch, Maximus of Tyre), people are warned against the flatterers who do not speak the truth but only use words of flattery to gain something. Therefore, $\pi \alpha \rho \rho \eta \sigma i \alpha$ became a duty between true friends. In Philosophic writings and discussions, $\pi \alpha \rho \rho \eta \sigma i ́ \alpha$ was seen as a therapeutic element and duty of the psychagogue (cf. Philo, Quis heres 19, 21; De migr. 116-117; Plutarch, Quomodo adulator 74D; Kok 2012). Excessive frankness was not desirable because it would not encourage but discourage moral growth whereas too little frankness will not lead to the desired transformation of character. Here wisdom, discernment and adaptability were needed. It was the responsibility of true friends to be

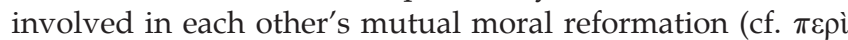
$\pi \alpha \rho \rho \eta \sigma i ́ \alpha \varsigma \alpha v \delta \pi \varepsilon \rho \grave{~} \varphi \imath \lambda i ́ \alpha \varsigma$ [On frank speech and friendship]; cf. Fitzgerald 1998:5; Kok 2012). Elsewhere Philodemus (cf. De. Lib. Dic. Col. VIIIb) refers to the mild form of $\pi \alpha \rho \rho \eta \sigma i ́ \alpha$ which finds its expression in the way two wise sages engage with one another in mutual respect and in expectation of high standards. They will often 'sting each other with the gentlest of stings, and will thank the other for the honest $\pi \alpha \rho \rho \eta \sigma i \alpha^{\prime}$ afterwards (Sampley 2004:298).

Epictetus, like Musonius Rufus and even Philodemus (On frank speech, Fr. 67.1-10; especially Fr. 68-69), draws the analogy between the skilful philosopher and the physician (cf. Musonius Rufus, Fr. 36; Epictetus, Discourses 3.23.30-32; 3.21.8-9. 17-20). One of the prerequisites for being a true psychagogue was that the sage must have been able to 'diagnose' his 'patients' appropriately to know which kind of remedy would be applicable; he should also have been of sound character. ${ }^{9}$ A wise psychagogue would have adapted his conduct to meet the diversity of needs of his patients because he was dedicated to the reformation of their character (Glad 1995:86). The flatterer had in mind his own selfish needs and personal advantage (Glad 1995:23; Aristotle, Nicomachean ethics 1173b31; 1108a26; 1126b12-15; 1127a7-9) whilst the wise philosopher had in mind the character and health of his hearer (cf. also Philodemus, On frank criticism, Fr. 43.4-10). The psychagogue would exhort those he wanted to reform, like a father would exhort his children,

9.According to Philodemus (On frank criticism, Fr. 46.1-11), the wise sage should be sound himself if he wants to heal others: 'For how is he going to hate the one who makes a mistake, when he knows that he himself is not perfect, and reminds himself makes a mistake, when he knows that he himself is not perfect, and reminds himself time and again that everyone is accustomed to making mistakes?
Philodemus, cf. also the translation of Fitzgerald 1998:58-59). sometimes with harsh words and at other times with soft words, depending on the type of exhortation needed in that particular context (cf. Aristotle, Nicomachean Ethics 1127a3-6; 1 Cor 4:14-21; 2 Cor 13:1-4; cf. Kok 2012). James also acts like a true friend who would sometimes use very harsh words in his letters to facilitate the reformation of the morality of

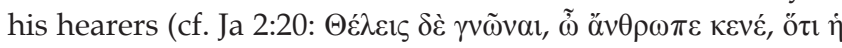

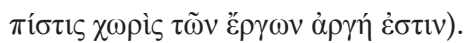

\section{James on wholeness and the problem of status differentiation}

James has in mind the wellness and wholeness of his congregation. Like Paul, James does not tolerate schism and status differentiation in the congregation, and he uses firm speech to make his point clear. In 2:1-13, James addresses the problem of partiality in the congregation and exhorts (cf. imperative $\varepsilon \chi \chi \varepsilon \tau \varepsilon$ [do not have]) the believers to allow no

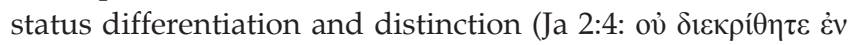

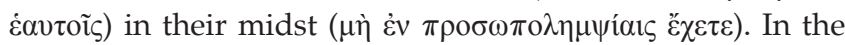
first century, the clothes you wore said who you were. In this case, it seems that poor and rich Christians so-existed in the congregation, ${ }^{10}$ and that on this particular occasion, it happened that a person with bright clothing ( $\dot{\varepsilon} \sigma \theta \tilde{\eta} \tau \iota \lambda \alpha \mu \pi \rho \tilde{\alpha}$ in 2:2) entered the assembly. Suddenly, everyone made way to give this person(s) the honourable seat in the place of assembly, degrading the poor people to their proper place, namely at the host's feat or standing somewhere separate, outside of the 'circle of influence'. The problem in this congregational setting is something that was also a problem in Corinth, namely that extra-congregational life and values were brought into the intra-congregational context (cf. Kok 2012; Wolter 2006:199-217). This was the same problem that Paul addressed in 1 Corinthians when he exhorted the believers not to let the diversity and schism in their midst drive them away from one another but that they should focus on corporate solidarity in Christ, self-sacrificial love and other-regard (cf. 1 Cor 1:10; 11:1; 13:1-13). James makes it clear that, when distinctions are drawn between people in the context of the community of faith and the context of the

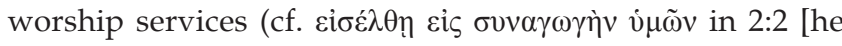
comes into your meeting]), they commit a sin and do not live according to the fundamental values of the Christ-following community. Just like Paul, James makes it very clear that the ethos of Christ-followers equalises the status distinctions prevalent in the world. In the context of the church, believers are all equal. Wolter (2006) rightly expresses it with reference to Paul, but it is similarly applicable to James in this context:

Common faith in Jesus Christ and baptism constitute a common identity, which is predominant over any other identity that is ascribed to the members of the Christian community within other symbolic universes and social systems. It is of crucial importance

10.The pagan author Celsus (Origen, Contra Celsus 3.44), who wrote against Christianity argued that Christianity excluded educated people since the movement only attracted the foolish, dishonourable and stupid, and only slaves, woman and little children (Meeks 1983:51; cf. also MacDonald 2003). Deismann (1908; cf. also 1910; see Meeks 1983:52), professor of New Testament in Berlin, at first agreed with this perspective since the Greek of the New Testament, for instance that of Paul, represented an illiterate Greek, and Paul as missionary continued to work amongst the illiterate masses. Since the 1980s, most scholars started to realise that this perspective was not correct (see Meeks 1983:52). Here in James is one example of reference to rich believers who entered the assembly. 
that the communality and the exclusivity of this identity 'in Christ', which eclipses any other ethical, social, and cultural differences, can also be experienced as a social identity. (p. 202)

Paul makes explicit used of baptismal unity formulas like Galatians 3:28 and 1 Corinthians 12:13 where he clearly states the theological concept that there is no differentiation between male and female or slave and free in the context of the community of faith. James does not say it explicitly, but implicitly this can be seen as the basis of his exhortation as well. According to James, there should be no distinctions between rich and poor due to the fact that, in Christ and as part of the same family, believers are all brought forth by God and are thus fundamentally equal. Distinctions between rich and poor and honour showed to some members based on their financial capability were nothing less than taking part in evil thoughts the origins of which could not have been Christ and which could therefore not be sustained by believers

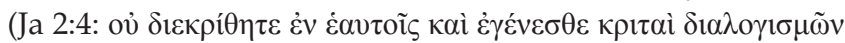
$\pi$ ovๆ $\rho \tilde{v} v$ [Have you not discriminated amongst yourselves and become judges with evil thoughts]). Such thoughts and conduct, such ethos, should be abandoned by those in the community of faith (see Kok 2012). The opposite of such conduct is that believers will make no distinctions based on the criteria of financial means but regard each other as equals. The underlying principle on which James is building his argument is that God has chosen those who are poor in the eyes of the world but that they were the ones that would become rich in faith, heirs not of earthly riches and kingdoms but of the kingdom of God (2:5). Therefore, believers should keep the bigger picture in mind. The bigger picture revolves around the missional plan of God. God took the initiative to choose the poor of this world. The ethos of this community, as an alternative fictive community with God as their father, derives from their identity, and they should therefore also embody the (ethical) values of their father. One of the most important things in this family, according to James, is that '[y]ou shall love your neighbour as yourself' (Ja 2:8). This comes down to radical other-regard and forms the opposite of self-regard and partiality whereby some are regarded with honour whilst others are not. Within the community of faith, other-regard and impartiality should be the ethical norm. This means that the values of the world are turned upside down in the context of the church. In a highly stratified world with competition and love of honour, the believer seeks only the honour of God and respects the honour of each member within the community of faith. This alternative community of other-regard will be known for their ethos which puts the other member's needs before their own. Concretely speaking, they would be quick to listen rather than quick to speak,

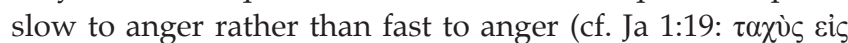

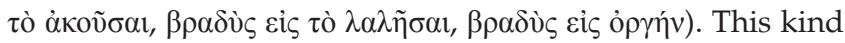
of conduct derives from an inner disposition, namely that the God of lights, who has no shadow or darkness in him, brought us forth as first fruits of his creation. Believers share the 'DNA' of this divinely created family. This is typical of the argumentation of early Christianity, for instance in 1 John 1:5, which also clearly states that God is light and that there is no darkness in him. Those who have fellowship with the light will not walk in darkness for they are begotten children of God, says John (Jn 3:3, 6), and they have the seed and nature of God in themselves (1 Jn 3:9). In the same way, James argues that God has, by his own will, begotten us with the purpose of being a kind of first fruit of his creation (Ja 1:18: ßov $\lambda \eta \theta \varepsilon$ $\dot{\alpha} \pi \varepsilon \kappa v ́ \eta \sigma \varepsilon v \dot{\eta} \mu \tilde{\alpha} \varsigma$ [Because he wanted to, he gave us birth ...]). His begotten ( $\dot{\alpha} \pi \varepsilon \kappa v ́ \eta \sigma \varepsilon v)$ children, by the word of truth (Ja 1:18: $\lambda$ ó $\gamma\left(\dot{\alpha} \lambda \eta \theta \varepsilon i \alpha_{\varsigma}\right)$, are thus called to be witnesses to God's nature in their way of thinking and doing. God is the creator of life whilst human desire and sin lead to death. Being born from God results in a life in opposition to sin, which leads to death (Ja 1:15). Believers have the responsibility to cast off that which is still part of their old existence, namely the existence before they became part of God's family. James explicitly says that, when believers discriminate against poor believers and give rich believers more honour, they are

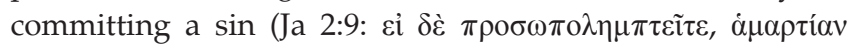
$\dot{\varepsilon} \rho \gamma \alpha \dot{\zeta} \zeta \varepsilon \sigma \theta \varepsilon$ [If you show favouritism, you sin]). Believers are people who should focus on other-regard and not their own

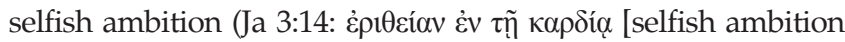
in the heart]). Concretely, such pure love and other regard will find expression in the visiting of orphans and widows in contexts of affliction (Ja 1:26-27). ${ }^{11}$ This, in my opinion, is missionary in its very nature. Stark mentioned that, in the first few centuries, it was exactly this kind of conduct that lead to the rapid spread of Christianity. In times of conflict, sickness and disease, the Christians cared not only for their own but also for those for whom nobody else cared (see Stark 1997:75-94). James says that Christ-followers seek wisdom from above, which is pure, peaceable, gentle, open to reason, full of mercy and good fruits, without uncertainty or insincerity (Ja 3:17). Most importantly, this wisdom from above, if one lives according to it and does what one believe and confess, is sown in peace by those who make

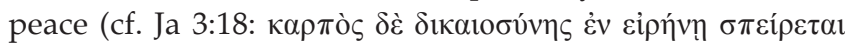

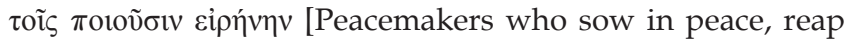
righteousness]). On its part, peace relates to reconciliation. God's begotten first-fruit people who live according to their identity, begotten from the father, have all been reconciled to God and will also be those who are characterised by the ethos of making peace. Selfish ambition and jealousy result in the opposite of peace and reconciliation whilst other-regard and love for the neighbour will result in peace and reconciliation. Selfish ambition is friendship with the world, which causes wars and fighting amongst believers (Ja 4:1: Пó $\theta \varepsilon v$ ió $\lambda \varepsilon \mu$ or

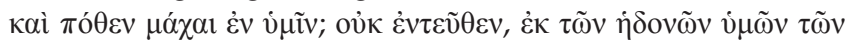

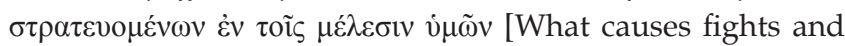
quarrels amongst you? Do they come from your desires and battle within you?]). Selfish ambition, according to James, is the cause of all kinds of disorder and vile practice (cf. Ja 3:16:

11.Macdonald (2003:173) remarks that, in early Christian literature, the care of widows and orphans was often paired together and seen as a duty of the church (cf. Ja 1:27; Herm. Man. 8.10; Barn. 20.2; Ign. Smyrn. 6.2; Jr 7:6; Dt 24:19-22. According to MacDonald, the sources indicate that children were involved in the spreading of the gospel and the expansion of the movement. Children were active participants the gospel and the expansion of the movement. Children were active participants in the Christ-followers movement, as seen in the household codes (cf. Col 3:20; Eph 6:1-2). In Ephesians 6, the author provides teaching on the relationship between parents and their children and the expectations they could have of one another According to Celsus, Christians tried to influence children (MacDonald 2003:174) and some Christian children were engaged in missionary activity like Laeta's daughter, reported by Jerome (letter 107, Jerome to Laeta): 'When she sees her grandfathe, she must leap upon his breast, put her arms around his neck, and, whether he like it or not, sing Alleluia in his ears' (Jerome, quoted by MacDonald 2003:174-175). 


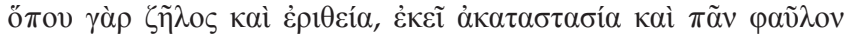
$\pi \rho \tilde{\alpha} \gamma \mu \alpha$ [Where you have encyt and selfish ambition, you will find disorder and every kind of evil practice]).

Like a typical psychagogue, James exhorts the believers not to make themselves friends to the world (Ja 4:4). He uses harsh words and not words of flattery, calling double-minded

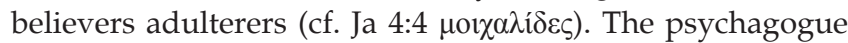
would often employ honest and harsh words as a true friend with the intention of 'healing' the 'illness' of the friend. James says that those who are friends with the world are enemies of God. John says the same in 1 John 1:5 'God is light and there is no darkness in him. If we say that we have fellowship with him, while walking in darkness, we lie and do not live

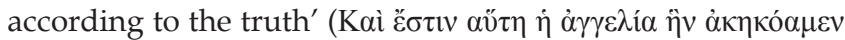

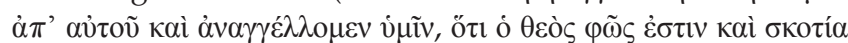

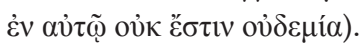

James' advice revolves around self-sacrifice and submission (see Figure 1).

James 4:7-10 forms a clear chiastic structure with the focus on becoming humble and submitting to the Lord. It is qualified by fleeing from the source of opposition to God and turning to the source of truth and light, which is God. This is where the Epicureans and the Christ-followers parted ways. The former always based their motivation on reason or nature, the latter always on God as primary initiator of the relationship and submission to his will. The result of the Christ-follower's action of submission will lead to God drawing near to the believer as a consequence of the believer's turning away from the devil. When this turning towards God has taken place, it results in the cleansing and purification of hands and heart, signifying the deeds and the intention behind the deeds. Hands and heart represent the totality of the person that is cleansed. Such a person will be made free of double-mindedness. Worldly joy that was based on the wrong motivation will be transformed into repentant mourning, illustrating the transformed realisation

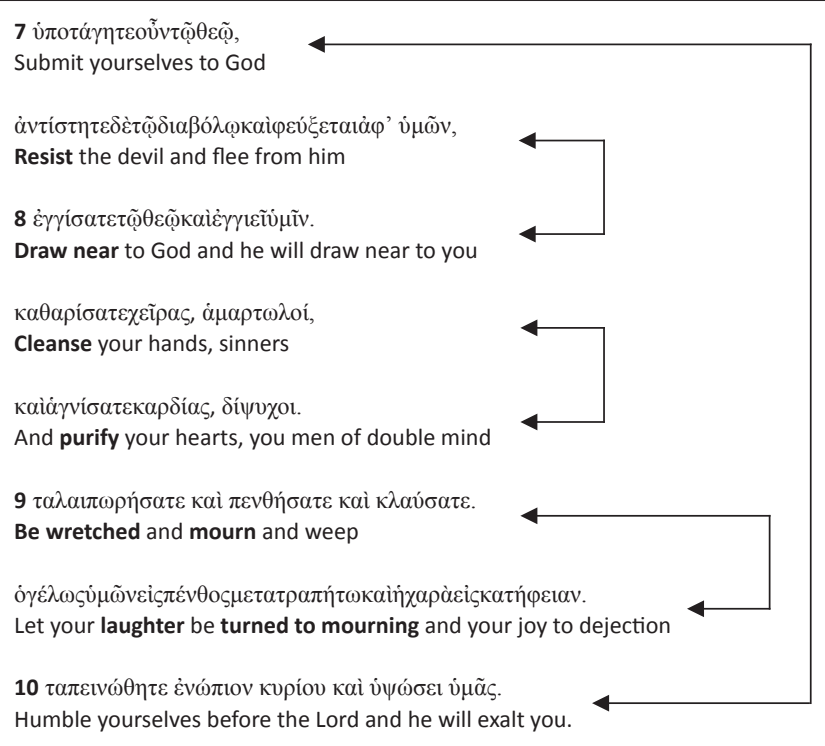

FIGURE 1: James 4:7-10: Quotes by James. of guilt and the implicit humbling of the self before God. The $\tau \alpha \pi \varepsilon เ v \omega \dot{\theta} \theta \tau \varepsilon$ [humbleness] in the face of the Lord leads to a restored exaltation, not in a worldly way but in a restored spiritual way. Such an exalted person will be humble, free of boasting, free of self-regard and full of peace. In the context of the congregation, such a person will not speak evil against a fellow believer and will not judge a friend but will focus on other-regard. The transformed state of mind will also lead the believer to realise that future plans and future projections are like boasting since the future is not in the hands of the person but in the hand of God (Ja 4:13-17).

Furthermore, it becomes clear that, in his pastoral leadership strategy, James functions like a psychagogue. In the Phaedrus, Plato referred to $\psi v \chi \alpha \gamma \omega \gamma i$ [psychagogy] as an art whereby an orator would guide the listener to the truth by adapting his words to the nature of the listeners' soul, of which Socrates was a good example (Glad 1995:18). One of the primary functions of a psychagogue was to facilitate the formation of self in neophytes, to help them to create a sense of identity and a sense of what distinguishes them from society at large, to establish an in-group mentality and loyalty and to guide their behaviour in a way that is aligned with the implicit values of the group to which they converted (Glad 1995:10). This was not only the function of the psychagogue but also that of the social group, both in Epicurean and in early Christfollowing communities. The aim, as Glad (1995) says, was to establish a sense of corporate solidarity:

The diversity of members in both communities gives an added poignancy to the need for accommodation and communal unity. What unites the friends of the proto-Christian communities and the Epicureans, indeed, what constitutes their 'likeness' is not virtue or character but a unity or likeness of purpose. In pursuit of their respective communal goals, participatory psychagogy as a social practice was important, not only as a solidarity mechanism but also a defining characteristic of the community, a sine qua non of the fellowship. This communal practice is not ancillary but constitutive of both communities and establishes as form of community ethos which binds members together in their common purpose. (pp. 10-11)

Fitzgerald (1998:8) agrees and refers to Philodemus' On frank criticism, which paints a picture of psychagogy that actually depends on the active contribution and participation of all members within the group, not only the leader - all members have the responsibility to correct each other. It would therefore often happen that the leader and the members publicly admit to mistakes and personal faults in order to create an environment of mutual moral development and continual importance of moral regeneration and responsibility. Philodemus' fragments reveal that it was dishonourable to conceal moral shortcomings and not to be open and take part in self-disclosure. Such persons could not be healed, and the therapeutic intention of the group could not transform the individual (cf. Philodemus, On frank criticism, Fr. 81-84; Col. XVIIa). ${ }^{12}$ As mentioned above, true friendship is characterised by frank speech, which is intended to correct wrong behaviour in a friend and aid in the friend's

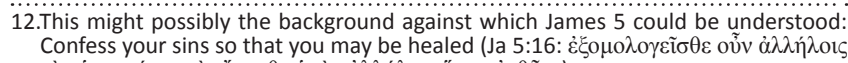

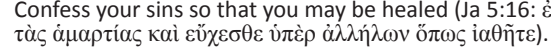


moral growth - getting them back on the right track. One finds ample reference to the analogy of the physician-patient relationship in which $\pi \alpha \rho \rho \eta \sigma i \alpha$ [frank speech], although it stings and hurts at first, is like honey in that it heals the broken places and cleanses them too (cf. Plut., Quomodo quis suos 59D; quoted by Sampley 2004:296; Philodemus, On frank criticism, Col. XVIIa).

Likewise, it seems to me that James expects the community of faith to take responsibility for one another's spiritual health. In James 5:13-18, he exhorts the believers to pray for those amongst them that are sick. The question is what is meant by the reference to those that are sick. Medical anthropological insights distinguish, in the 1st-century Mediterranean world, between the curing of a disease and the healing of an illness (Kok 2008:1-20; Pilch 2000). The curing of a disease refers to biological curing of some form of biological sickness. Healing, in contrast, refers to the restoration of (lost) meaning that might or might not include physical healing (cf. Pilch 2000) and often included social integration after some cause of misconduct separated an individual from the group (Kok 2008:1-20). In my opinion, James is not necessarily referring to prayer that would lead to the curing of biological disease but rather to the spiritual healing that would result when the community of believers confess their sins amongst each other and create the environment in which corrective group processes could help in the moral reformation of

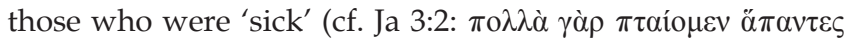
[For we all make mistakes]). This is something that is not strange in Epicureanism.

In his conflict management strategy, the implicit ethics of reconciliation and communal concord plays a fundamental important role in James' rhetorical argumentation and the resolution of the conflict situation in his congregation. Furthermore, the ethics of reconciliation ${ }^{13}$ relates to the narrative of God's initiative, God who begets a family of first-fruits who are intended to carry the nature of God in the way they conduct themselves in the world. As he is light and life, the believers should not only participate in this spiritual reality but also live in a way that illustrates that they are children of God. James accentuates the fact that faith without works is dead. One can believe in God, the source of light and life, but if one does not show the corresponding works that witness to that fact, one's faith is simply dead. Such a person is double-minded. In James 3:10-12, he exhorts his congregation, pointing out that this kind of doublemindedness cannot be sustained:

This ought not be so. Does a spring pour forth from the same opening fresh water and brackish water? Can a fig tree yield olives or a grapevine figs? No more can salt water yield fresh water.

13.James does not use the term reconciliation, but that does not mean that the semantic domain does not exist implicitly within the structure of his argument. Breytenbach (2010:172-173) rightly indicates that the process of reconciliation Breytenbach (2010:172-173) rightly indicates that the process of reconciliation denotes making peace, changing from enmity to friendship. Hesychius, as referred to by Breytenbach, relates to Eip James, although he does not use the word 'reconciliation', the semantic meaning making peace and restoring relationships is very clear. This is where scholars like Bash (1997:30-32) miss the point when they do not take into consideration

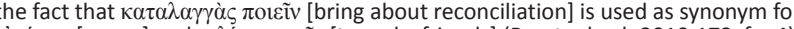

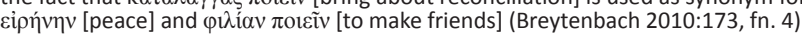

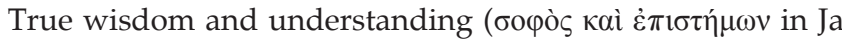
3:13) is illustrated when a believer does good works, flowing

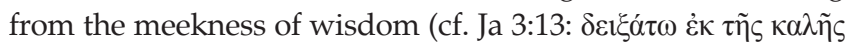

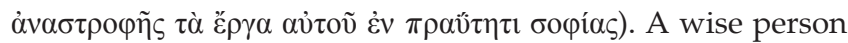
is not an 'earthbound, sensual or demonic' self-ambitious

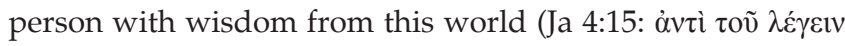

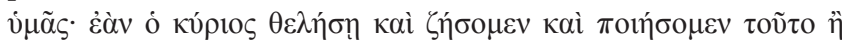
$\dot{\varepsilon} \kappa \varepsilon \tilde{v}$ o [Instead you ought to say, 'If this is the will of the Lord, we will live and do this or that']) but a person with humble self-sacrificial wisdom ( $\dot{\varepsilon} v \pi \rho \alpha \hat{u} \tau \eta \tau \imath ~ \sigma o \varphi i ́ \alpha \varsigma$ in James 3:13 [humility that comes from wisdom]) that comes from above [from God] (; cf. Ja 3:8, 4:1). Believers who concretely live this way will be wise, and they will create a healthy community. Philodemus (On frank criticism, cf. Col XV11a$\mathrm{XVIIIb)}$ argues that a person who is not open to frank speech is someone who does not acknowledge his own errors and is also not someone likely to improve or grow on a moral level. Such persons can easily make jokes about others and provide frank speech, but they have trouble in accepting it with humble wisdom when they receive it. Contrary to reason, they believe that they have not erred (Philodemus, On frank criticism, COL. XVIIIb.10).

\section{Acting according to identity}

Epictetus reminds his readers: 'You are bearing God about with you, you poor wretch, and you do not even know it.' According to Epictetus, '[ $i] \mathrm{t}$ is not an external God made of silver or gold, but it is within you that you bear Him. You do not know that you are defiling Him with impure thoughts and

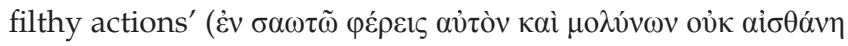

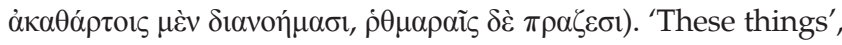
argues Epictetus, 'you will not do in the presence of even an image of God, yet when God is present within you, seeing and hearing all you do, you should be ashamed.' Epictetus then stings with his words: 'O how insensible of your own nature, which is nothing less than an object of God's wrath.' The problem with such people is that they do not know the God within them; they do not know the (ever present) companion with whom they are setting forth. Epictetus says that if you were a statue of Pheidas, Athena or Zeus, you would have remembered who you were and who created you (your artificer) (cf. Ja 1:24 concerning looking in mirror and forgetting). If you had this perception, you would have tried to do nothing unworthy of him that had fashioned you or of yourself, and you would have tried not to appear in an unbecoming attitude before the eyes of men (my translation adapted from the original translation by Oldfather 1946: 259-265). The problem Epictetus describes is that people do not act according to their nature or according to the kinship to which they belong. This is the same problem Paul, John and James had with believers who said that they believed but then went on and lived in a way contrary to their (re)created identity. Paul says that believers are a new creation and should live as people who have been recreated and put into God's family (2 Cor 5). John does the same; believers have been transferred from death to life (Jn 5:24) and should live according to their newly created identity as God's children. Epictetus also focuses on the responsibility that believers 
have not to dishonour the work of the Craftsman. Not only did God create you, but he has entrusted and committed you to yourself alone, and moreover, by forgetting, do you not by implication dishonour your trust? (Epictetus, Discourses II, 8, 21-23; cf. Oldfather 1946:259-265). Epictetus argues that:

God has delivered your own self into your keeping like an orphan, to your care, to be kept unchanged from the character with which nature has endowed him, namely reverent, faithful, high-minded, undismayed, unimpassioned, unperturbed. (My translation adapted from the original translation by Oldfather 1946:265).

In his Discourses (Book 2, Chapter 9), Epictetus continues the argument and exhorts the reader:

See to it that you never act like a sheep, for if you do, the man in you is destroyed in this way also. You act like a sheep when you act for the sake of your belly, or for the sake of your sexual organs, or at random, or in a filthy fashion, or without due consideration. If you act that way, says Epictetus, you have been degenerated to the level of a sheep, and you would have destroyed reason. (My translation adapted from the original translation by Oldfather 1946:267-269).

In the same way, other negative moral behaviour, like when a person act pugnaciously, angrily and rudely, means that such a person degenerates to the level of irrational beasts. Epictetus argues that a flute fulfils its purpose when it functions as a flute. Therefore 'deeds that correspond to his true nature strengthen and preserve each particular man' carpentry does that for the carpenter, grammatical studies for the grammarian. But if a man acquires the habit of writing

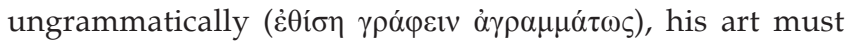

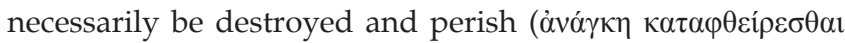

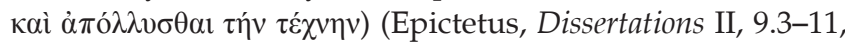
here 8-11; my translation adapted from the original translation by Oldfather 1946, 268). So, modest acts preserve the modest

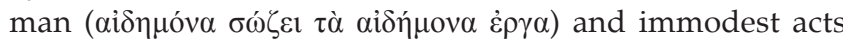

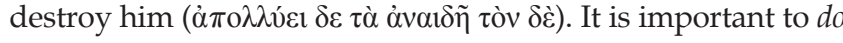
the things you know (Epictetus, Dissertations II. 9.1-22), and not only speak about it. ${ }^{14}$

\section{Mutual responsibility}

Fittingly, James concludes his letter with a hortatory appeal to mutual responsibility, which, according to Martin (1988), sums up the overall purpose of the letter, namely that James intents his readers to be turned from error. James 5:19 reads:

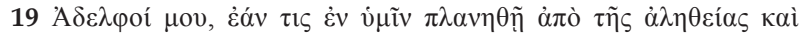

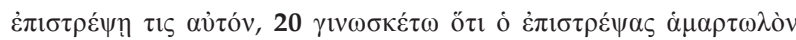

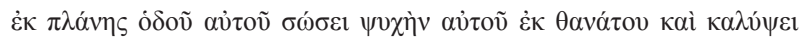
$\pi \lambda \tilde{\eta} \theta 0 \varsigma \dot{\alpha} \mu \alpha \rho \tau i \tilde{\omega} v$. [19 My brothers, if one of you wanders away from the truth and somebody brings him back; 20 you may be sure that whoever brings a sinner back from his wrong path will save his soul from death and cover a multitude of sins. $]^{15}$

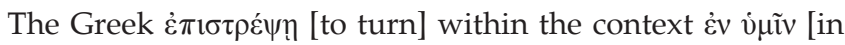
you] expresses the fact that the conversion takes place within

14.For the idea that the individual cannot act as an individual but as part of a body and that there should be correspondence between one's designation and behaviour, see Epictetus (Discourses, Book II. X.). Epictetus also uses the metaphor of the body as a unity and the fact that identity determines appropriate behaviour. Both body as a unity and the fact that identity determines appropriate behaviour. Both identity and ethos. Both describe the problem of people who have forgotten who they are and what their designation is.

15.Translation form the Standard International Version. the context of the community of faith and is not in the first instance meant to be understood as ' $n$ missionary intension to the outside (cf. also Brosend 2004). Martin (1988) is correct in arguing that 'James has not left the straying person to care for himself but has placed the burden of "reclamation" upon those of the church who are still in the fold.' James has in mind the corporate responsibility of believers to correct the wrong ways of fellow believer and to lead them on the right path (correctio fraterna) so that they might be reconciled and restored in their relationship with God. The purpose of such action is that such a person that converted from wrong ways, will be saved from (spiritual) death (cf. Ezk 33:11; Dt 30:19; Pr 12:28). At the end, this is the will of God - that a sinner be turned back to fellowship, restoration and reconciliation. Unlike Paul, James does not use the word reconciliation explicitly (cf. Ezk 34:11-16). Martin sums it up well when he claims ' $[t]$ he Christian who is walking the way righteousness is responsible for the "wanderer" ... ' It is interesting to note that Philodemus, in a context where he speaks of frank speech, also refers to the fact that people are helped in the process of frank speech and that if you will

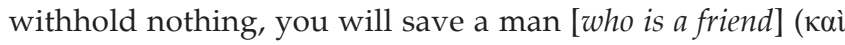

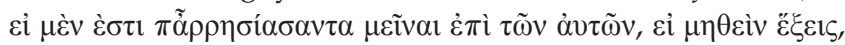

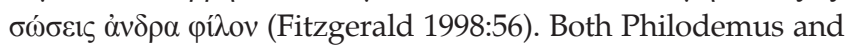
James speak of the moral restoration that will take place in the context where a drifter has been led back to her or his true identity and is guided on the right path, leading to healing (cf. Philodemus, On frank criticism, Fr. 77-78).

In my opinion, the dynamic relationship between continuing mission and ethical formation is an imperative for the church. The wise believer, who has been set free, will have a passion to help others experience that freedom for themselves and take responsibility for those within the community of faith who have lost their way. James would certainly agree with Philodemus on this point, namely that all believers are called to be psychagogues, taking responsibility for mutual moral growth, albeit for the sake of the gospel of life and the God who initiated it all.

\section{Acknowledgements Competing interests}

The author declares that he has no financial or personal relationship(s) that may have inappropriately influenced him in writing this article.

\section{References}

Bash, A., 1997, Ambassadors for Christ: An exploration of ambassadorial language in the New Testament, Mohr Siebeck, Tübingen. (Wissenschaftliche Untersuchungen zum Neuen Testament 2/92). PMCid:232506

Breytenbach, C., 2010, Grace, reconciliation, concord: The death of Christ in GraecoRoman Metaphors, Brill, Leiden. PMCid:3007557

Brosend, W.F., 2004, James and Jude, Cambridge University Press, Cambridge. (New Cambridge Bible Commentary).

Deismann, G.A., 1908, The philology of the Greek Bible: Its present and its future, transI. L.R.M. Strachan, Hodder \& Stoughton, London.

Deismann, G.A., 1910, Light from the ancient East: The New Testament illustrated by recently discovered texts of the Graeco-Roman world, transl. L.R.M. Strachan, Hodder \& Stoughton, London.

Fitzgerald, J., Obbink, D., \& Holland, G.S., 2004, Philodemus and the New Testament World, Brill, Leiden. 
Fitzgerald, J. (ed.), 1998, Philodemus: On frank criticism, introduction, translation and notes by D. Konstan, D. Clay, C.E. Glad, J.C. Thom \& J. Ware, Society of Biblical notes by D. Konstan, D. Clay, C.E. Glad, J.C. Thom \& J. War
Literature Texts and Translations, Scholars Press, Atlanta.

Glad, C.E., 1995, Paul and Philodemus: Adaptability in Epicurean and Early Christian Psychagogy, Brill, Leiden.

Kok, J., 2008, 'Siekte en gebrokenheid teenoor genesing en restourasie in Johannes' ongepubliseerde PhD-verhandeling, Departement Nuwe-Testamentiese Studie, Universiteit van Pretoria.

Kok, J., 2012, 'Mission and Ethics in 1 Corinthians: Reconciliation, corporate solidarity and other-regard as missionary strategy in Paul', HTS Teologiese Studies/Theological Studies 68(1), Art. \#1222, 11 pages. http://dx.doi.org/10.4102/hts.v68i1.1222

Kok, J. \& Van Eck, E., 2011, Unlocking the world of Jesus, Biblaridion, Pretoria.

Konstan, D., Clay, D., Glad, C.E., Thom, J.C. \& Ware, J. (transl.), 1998, Philodemus: On frank criticism, Society of Biblical Literature Texts and Translations, Scholars Press, Atlanta.

MacDonald, M.Y., 2003, 'The role of woman in the expansion of Early Christianity', in D.L. Balch \& C. Osiek (eds.), Early Christian families in context: An interdisciplinary dialogue, pp. 157-184, Eerdmans, Grand Rapids.

Malherbe, A.J., 2006, Paul and the popular philosophers, Fortress Press, Minneapolis. (Originally published in 1986/1987 with Fortress Press; Kindle Books electronic version 2006).
Martin, R.P., 1988, James, Word Books, Texas. (Word Biblical Commentary Series, vol. 48). Meeks, W., 1983, The first urban Christians, Yale University Press, New Haven.

Pilch, J., 2000, Healing in the New Testament: Insights from medical and cultura anthropology, Fortress Press, Minneapolis. PMCid:112173

Oldfather, W.A. (transl.), 1924, Philodemus, On frank criticism, Loeb Classical Library, Cambridge, MA.

Rendall, G.H., 1927, The Epistle of James and Judaic Christianity, Cambridge University Press, Cambridge, UK.

Sampley, J.P., 2004, 'Paul's frank speech with the Galatians and the Corinthians', in J. Fitzgerald, D. Obbink \& G.S. Holland (eds.), Philodemus and the New Testament world, pp. 295-322, Brill, Leiden.

Sleeper, C.F., 1998, James, Abingdon Press, Nashville. (Abingdon New Testament Commentaries).

Stark, R., 1997, The rise of Christianity: How the obscure, marginal, Jesus Movement became the dominant religious force in the Western world in a few centuries, Harper, San Francisco.

Wolter, M., 2006, 'Pauline ethics according to 1 Corinthians', in J.G van der Watt (ed.), Identity ethics and ethos in the New Testament, pp. 199-218, Walter De Gruyter, Berlin. 